Article

\title{
2-Substituted Aniline as a Simple Scaffold for LuxR-Regulated QS Modulation
}

\author{
Sizhe Li ${ }^{1}$, Julien Wawrzyniak ${ }^{2}$, Yves Queneau ${ }^{1, *}$ and Laurent Soulère ${ }^{1, *}$ \\ 1 Univ Lyon, INSA LYON, Université Lyon 1, CPE Lyon, UMR 5246, CNRS, ICBMS, Bât. J. Verne, \\ 20 Avenue A. Einstein, F-69621 Villeurbanne, France; sizhe.li@insa-lyon.fr \\ 2 Univ Lyon, INSA Lyon, Université Lyon 1, UMR 5240, CNRS, MAP, 10 rue Raphaël Dubois, \\ F-69622 Villeurbanne, France; julien.wzk@gmail.com \\ * Correspondence: yves.queneau@insa-lyon.fr (Y.Q.); laurent.soulere@insa-lyon.fr (L.S.); \\ Tel.: +33-472-436-169 (Y.Q.); +33-472-438-342 (L.S.)
}

Received: 29 September 2017; Accepted: 27 November 2017; Published: 29 November 2017

\begin{abstract}
The ability of the 2-substituted aniline motif to serve as a scaffold for designing potential LuxR-regulated quorum sensing (QS) modulators has been investigated, using docking experiments and biological evaluation of a series of 15 specially synthesized compounds. Aniline, 2-acetyl-aniline and 2-nitroaniline were considered, as well as their $\mathrm{N}$-acylated derivatives. Docking experiments showed that the 2-substituted aniline motif fits within the LuxR binding site at the place of the lactone moiety of AHL, and the biological evaluation revealed QS antagonisitic activity for several compounds, validating the hypothesis that this scaffold acts on QS. Structure activity relationships are discussed regarding interactions with the key residues of the LuxR binding site, showing significant variations in the H-bonding pattern.
\end{abstract}

Keywords: quorum sensing; antagonists; 2-nitroaniline scaffold; molecular docking

\section{Introduction}

Bacterial quorum sensing (QS) is a communication system based on the biosynthesis of small diffusible molecules, called autoinducers, able to interact with proteins, in particular transcriptional factors [1]. This communication system, and, more specifically, its quenching using small molecules to fight bacterial virulence, has been extensively studied [2-7]. In Pseudomonas, to date, three QS systems have been identified [8]. Two of them are regulated by acyl homoserine lactones (AHLs), namely $\mathrm{N}$-3-oxo-dodecanoyl-homoserine lactone and $\mathrm{N}$-butanoyl-homoserine lactone, and they interact, respectively, with LasR and RhlR. Another system, called PQS (Pseudomonas quinolone signal), is regulated via quinolone derivatives. These compounds are biosynthesized from anthranilic acid, yielding HHQ [9]. Recently, a secondary metabolite from this biosynthetic pathway, namely 2-aminoacetophenone (2-AA), has been shown, by Kviatkovski and co-workers [10], to activate LuxR. In their work, they also used molecular modeling to demonstrate that 2-AA replaces the lactone, within the ligand binding site of a LuxR model, with hydrogen bonds between the $\mathrm{C}=\mathrm{O}$ and $\operatorname{Trp} 66$ and between the amine and Asp79. The 2-nitrobenzamide derivative TP-1 [11] (Figure 1) and other 2-nitrobenzamide derivatives have also been shown to be LasR modulators [12]. The X-ray-analyzed structure of the TP-1/LasR complex [11] shows that the 2-nitrobenzamide moiety, like 2-AA, is positioned at the same place as the lactone of AHL, with hydrogen bonding between the nitro group and Trp60 and also between the $\mathrm{NH}$ of the amide function and Asp73. These observations led us to investigate whether other 2-substituted anilines, in particular 2-nitroaniline (2-NA), act as new simple scaffolds for QS modulation. We report here the results of our study, using docking and biological screening, on a series of 2-acetyl-aniline and 2-nitroaniline compounds, as well as their $N$-acylated derivatives, as potential QS modulators. 


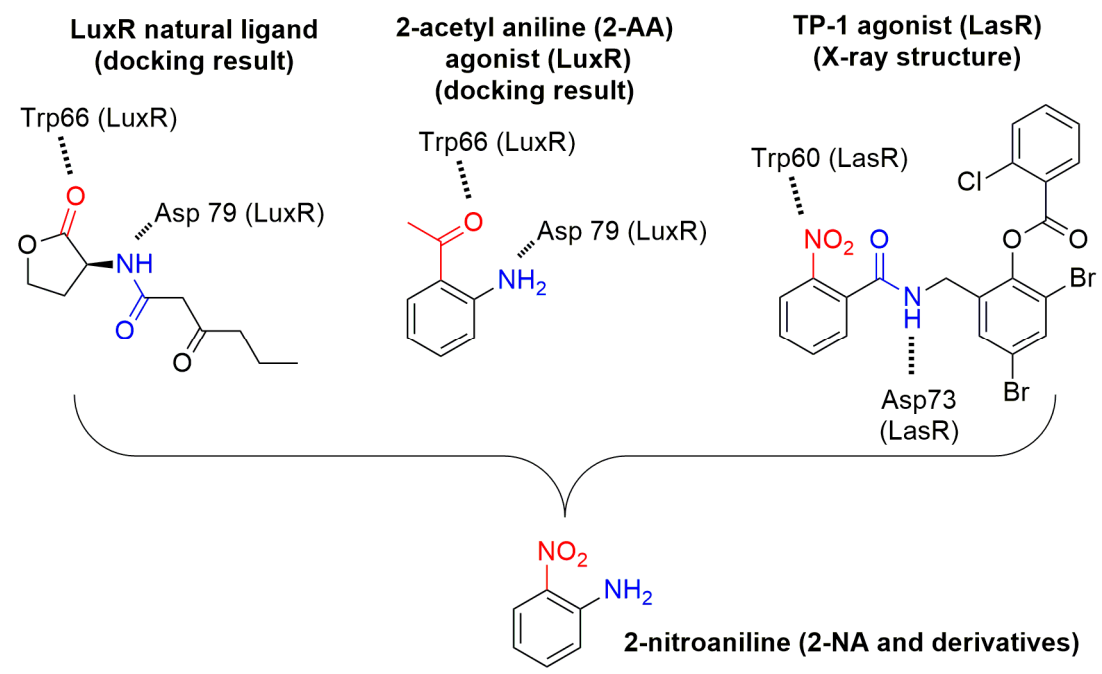

Figure 1. Structure-based design of 2-nitroaniline (2-NA) and derivatives (2-NA).

\section{Results and Discussion}

Flexible docking investigations [13,14] of N-3-oxo-hexanoyl-homoserine (OHHL) [15] and 2-nitroaniline using a LuxR model described in 2007 by Soulère and co-workers [16] showed that 2-nitroaniline is mimicking the lactone ring, notably forming hydrogen bonds between the nitro group (replacing the ester function of OHHL) and Trp66 (Figure 2).

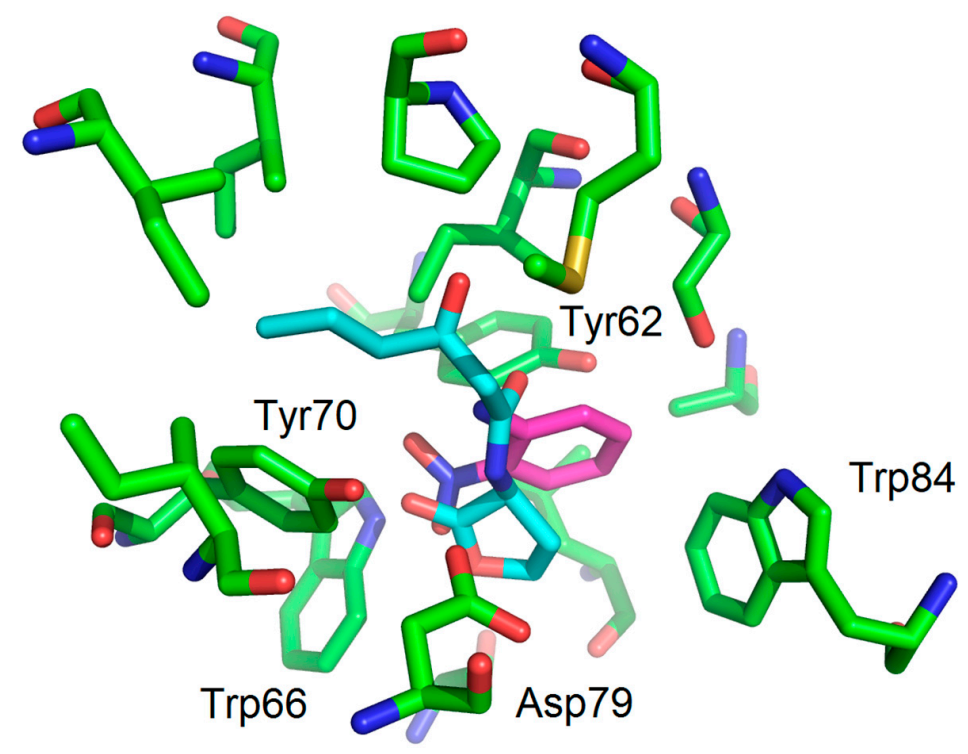

Figure 2. Proposed binding mode obtained as a result of docking experiments of 2-NA (magenta) within the LuxR model binding site. OHHL is also represented, in cyan. Docking experiments were performed using ArgusLab as software with a genetic algorithm as the docking engine (GADock) (see experimental section).

In keeping with the same structural analogy, in which the amine function of 2-NA or 2-AA (see supplementary data) and the NH group of the amide function of OHHL appear in similar positions within the binding site, we included in this study their $\mathrm{N}$-acylated derivatives, thus mimicking the amide side chain of AHLs. For comparison, we also investigated acyl anilines to examine the effect of this substituent in position 2 (Figure 3). 


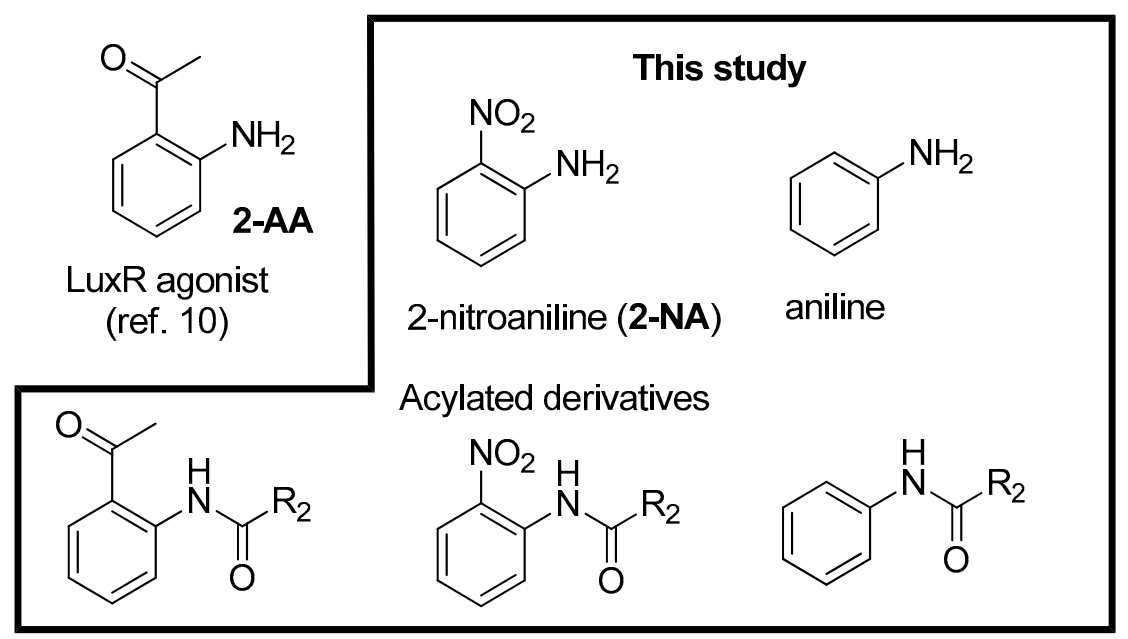

Figure 3. Structure of substituted anilines and their acylated derivatives.

All compounds were easily prepared from 2-NA [17], 2-AA or aniline by direct acylation with the corresponding acyl chloride (Figure 4). For compounds 5, 10, and 15, the acyl chloride was synthesized using oxalyl chloride from 4-phenylbutyric acid with catalytic dimethylformamide.<smiles>[R]c1ccccc1N</smiles><smiles>[R]C(=O)Cl</smiles><smiles>[R]C(=O)Nc1ccccc1[R]</smiles>

$$
\begin{aligned}
& \mathrm{R}_{1}=\mathrm{NO}_{2} \\
& \mathrm{R}_{2}=-\mathrm{C}_{3} \mathrm{H}_{7} \text { (1) } 85 \% \\
& \mathrm{R}_{2}=-\mathrm{C}_{5} \mathrm{H}_{11} \text { (2) } 57 \% \\
& \mathrm{R}_{2}=-\mathrm{C}_{7} \mathrm{H}_{15} \text { (3) } 52 \% \\
& \mathrm{R}_{2}=-\mathrm{C}_{9} \mathrm{H}_{19} \text { (4) } 43 \% \\
& \mathrm{R}_{2}=-\mathrm{CH}_{2}-\mathrm{Ph} \text { (5) } 29 \%
\end{aligned}
$$$$
\mathrm{R}_{1}=\mathrm{C}=\mathrm{OCH}_{3}
$$$$
\mathrm{R}_{2}=-\mathrm{C}_{3} \mathrm{H}_{7}(\mathbf{6}) 36 \%
$$$$
\mathrm{R}_{2}=-\mathrm{C}_{5} \mathrm{H}_{11}
$$$$
\text { (7) } 82 \%
$$$$
\mathrm{R}_{2}=-\mathrm{C}_{7} \mathrm{H}_{15}
$$$$
\text { (8) } 85 \%
$$$$
\mathrm{R}_{2}=-\mathrm{C}_{9} \mathrm{H}_{19}(\mathbf{9}) 37 \%
$$$$
\mathrm{R}_{2}=-\mathrm{CH}_{2}-\mathrm{Ph}(\mathbf{1 0}) 44 \%
$$

$$
\begin{aligned}
& \mathrm{R}_{1}=\mathrm{H} \\
& \mathrm{R}_{2}=-\mathrm{C}_{3} \mathrm{H}_{7}(\mathbf{1 1}) 92 \% \\
& \mathrm{R}_{2}=-\mathrm{C}_{5} \mathrm{H}_{11}(\mathbf{1 2}) 78 \% \\
& \mathrm{R}_{2}=-\mathrm{C}_{7} \mathrm{H}_{15}(\mathbf{1 3}) 92 \% \\
& \mathrm{R}_{2}=-\mathrm{C}_{9} \mathrm{H}_{19}(\mathbf{1 4}) 94 \% \\
& \mathrm{R}_{2}=-\mathrm{CH}_{2}-\mathrm{Ph}(\mathbf{1 5}) 88 \%
\end{aligned}
$$

Figure 4. Synthesis and structure of acyl aniline derivatives as LuxR modulators.

For the biological evaluation [18], all compounds were evaluated as agonists for their ability to induce bioluminescence in the $V$. fischeri QS system with a recombinant Escherichia coli biosensor. This biosensor strain produces luminescence with exogenously-provided AHL. None of them were found to be agonists, i.e., they did not induce bioluminescence. Compounds were also tested, at various concentrations, as antagonists in competition with $200 \mathrm{nM}$ of 3-oxo-C6-HSL (Figure 5).

Interestingly, these assays revealed that 2-NA, N-(2-nitrophenyl)butanamide (1) and $N$-(2-nitrophenyl)hexanamide (2) all displayed antagonist activity whereas other acyl derivatives, 3-10, were totally inactive. Based on the LuxR-QS system, compounds $\mathbf{1}$ and $\mathbf{2}$ exhibited $\mathrm{IC}_{50}$ values of $58 \mu \mathrm{M}$ and $94 \mu \mathrm{M}$, respectively, comparable with many other compounds described in the literature, thus validating our rational approach [5]. For acyl nitroaniline 3-5, with longer acyl chains (C8 and C10) or with a terminal phenyl group, their inactivity can be explained by an inappropriate size of the substituent $\mathrm{R}_{2}$, like what was observed for other structurally close AHL analogues with long chains [5]. As shown in Figure 6, docking experiments, with compounds $\mathbf{1}$ and $\mathbf{2}$ (nitro-C4 and nitro-C6) within the LuxR model binding site, revealed a satisfactory fit of these compounds, with a binding mode of hydrogen bonds between Trp66 and the nitro function and between Asp79 and the NH group. 
The aromatic part of the compound fits well and replaces the lactone moiety. The difference in activity for compounds $\mathbf{1}$ and $\mathbf{2}$ may be due to the change in the orientation of the alkyl chain.

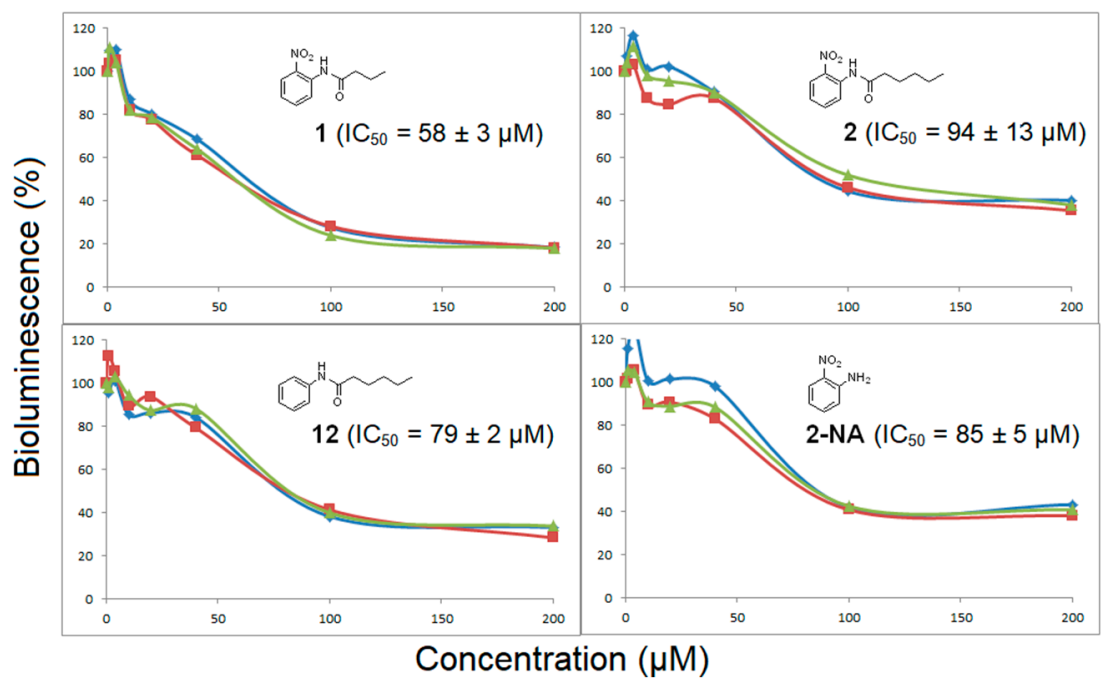

Figure 5. Antagonistic activity of 2-NA, and acyl 2-nitroaniline derivatives 1-2 and acyl aniline 12. Other derivatives were inactive (not shown). Bioluminescence was induced with $200 \mathrm{nM}$ of 3-oxo-C6-HSL. The experiments were carried out in triplicate shown in different colors.

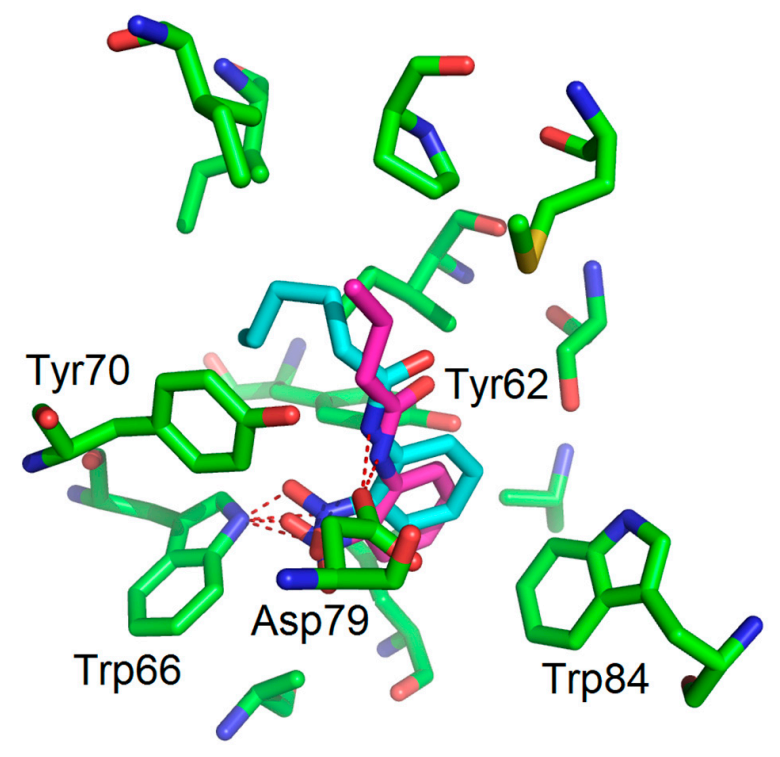

Figure 6. Proposed binding mode obtained as a result of the docking experiment with compound 1 (magenta) and 2 (cyan) showing that the phenyl group and the alkyl chain fit within the LuxR model binding site.

A comparison (biological evaluation and docking experiments) of 2-unsubstituted anilines was then performed. As already reported with LuxR for compound 14 [19], compounds 13 and 15 were found to be inactive. Interestingly, the hexanamide 12 showed significant antagonist activity, with an $\mathrm{IC}_{50}$ value of $79 \mu \mathrm{M}$, in the same range as $N$-(2-nitrophenyl)hexanamide (2). However, to our surprise, further shortening of the chain to $C 4$ (compound 11) led to a total loss of activity, whereas the corresponding nitrated counterpart was found to be the most active compound in this study. This shows that the two families of compounds behave differently, with a crucial nitro-substituent which anchors the molecules within the binding site, via a hydrogen bond with Trp66, and a less 
important chain length effect rendering both the $\mathrm{C} 4$ and the $\mathrm{C} 6$ derivatives active. On the other hand, for the unsubstituted aniline series, only one very specific derivative, the C6 amide, displays sufficient favorable interaction and sterical balance. This hypothesis is supported by docking experiments showing only one favorable binding mode for hexanoylaniline $\mathbf{1 2}$ within the LuxR binding site (Figure 7) whereas several binding modes, all unfavorable, were found for compound $\mathbf{1 1}$ within the LuxR binding site.

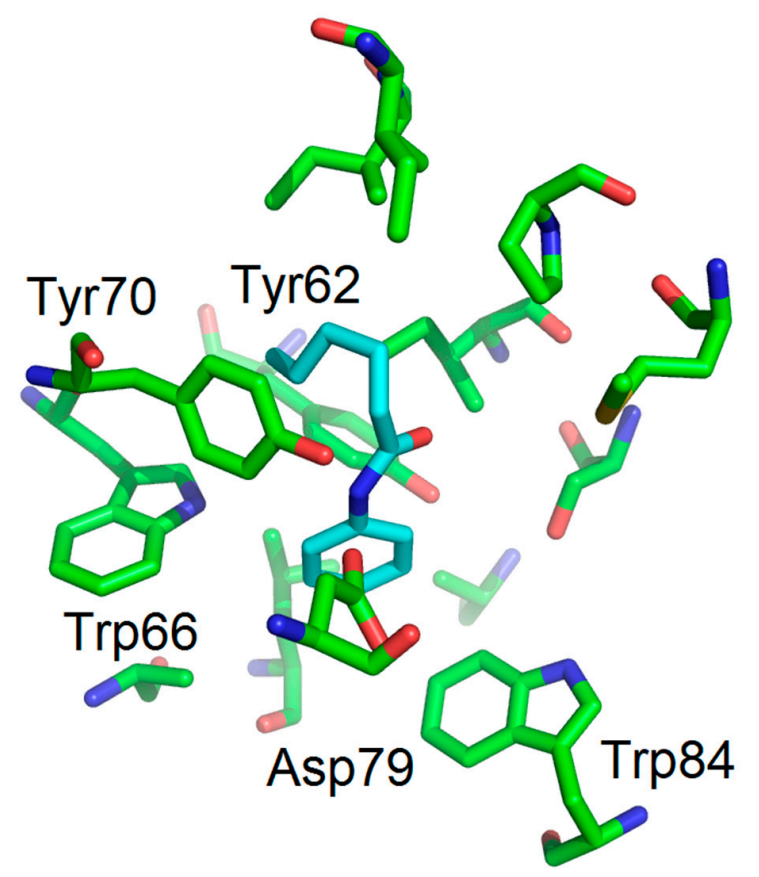

Figure 7. The binding mode (molecular docking) of compound 12 (cyan) shows a good fit, through hydrogen bonding, with Asp79 (NH).

We next examined the $\mathrm{H}$-bond interactions involving the important and conserved residues of the binding site (Trp66, Asp79 and Tyr62) for 2-AA, 2-NA, and compounds 1-2, 6-7 and 11-12, with the appropriate $\mathrm{R}_{2}$ substituents (Table 1 ).

Table 1. Occurrence and distances for hydrogen bonds between Trp66, Asp79, and Tyr 62 and the main chemical functions of studied compounds with distances $(\AA)^{\mathrm{a}, \mathrm{b}}$.

\begin{tabular}{cccc}
\hline Compounds & Trp66 & Asp79 & Tyr62 \\
\hline OHHL (natural ligand) & $+2.34(\mathrm{C}=\mathrm{O} \text { lactone })^{\text {a }}$ & $+3.01(\mathrm{NH}$ amide $)$ & $+3.01(\mathrm{C}=\mathrm{O}$ amide $)$ \\
2-AA (agonist) & $+2.20(\mathrm{C}=\mathrm{O})$ & $+3.03\left(\mathrm{NH}_{2}\right)$ & No function \\
2-NA (antagonist) & +2.96 and $2.37\left(\mathrm{NO}_{2}\right)$ & $-\mathrm{NH}_{2}$ too far & No function \\
$\mathbf{1}$ (antagonist) & $+2.47\left(\mathrm{NO}_{2}\right)$ & $+3.00(\mathrm{NH}$ amide $)$ & $-\mathrm{C}=\mathrm{O}$ too far \\
$\mathbf{2}$ (antagonist) & $+2.20\left(\mathrm{NO}_{2}\right)$ & $+3.01(\mathrm{NH}$ amide $)$ & $-\mathrm{C}=\mathrm{O}$ too far \\
$\mathbf{6}$ (No activity) & $+1.99\left(\mathrm{C}=\mathrm{OCH}_{3}\right)$ & $+3.10(\mathrm{NH}$ amide $)$ & $+2.97(\mathrm{C}=\mathrm{O}$ amide $)$ \\
$\mathbf{7}$ (No activity) & $+2.01\left(\mathrm{C}=\mathrm{OCH}_{3}\right)$ & $+2.98(\mathrm{NH}$ amide $)$ & $+2.94(\mathrm{C}=\mathrm{O}$ amide $)$ \\
$\mathbf{1 1}$ (No activity) & - & - & - \\
$\mathbf{1 2}$ (antagonist) & No function & $+3.04(\mathrm{NH}$ amide $)$ & $-\mathrm{C}=\mathrm{O}$ too far \\
\hline
\end{tabular}

${ }^{a}+$ indicates a possible $\mathrm{H}$-bond; ${ }^{b}$ the function implicated is indicated in brackets.

The autoinducer OHHL displays three hydrogen bonds with Trp66, Asp79, and Tyr62. The agonist 2-AA displays two hydrogen bonds with the same residues (none with Tyr62 due to the absence of the carboxamide function). In contrast, 2-NA, which shows antagonist activity, interacts only with Trp66, but in this case through two hydrogen bonds between Trp66 and the nitro group, and it does not interact with Asp79. The binding modes for 2-AA (agonist) and 2-NA (antagonist) are, therefore, significantly 
different with respect to the H-bond interactions. The acylated nitroanilines $\mathbf{1}$ and $\mathbf{2}$ display two hydrogen bonds, one with Trp66 and one with Asp79, whereas the simpler hexanoylaniline 12 shows only one hydrogen bond with Asp79. Thus, antagonists 1, 2 and 12 all display hydrogen bonds with Asp79 and Trp66 (if possible) but not with Tyr62. The combination of satisfactory overall binding and the absence of any interaction with Tyr62 appear to be a common feature among compounds showing antagonistic activity. For the inactive compound 11, docking experiments showed several binding modes due to the size of this compound and the absence of the nitro group. For compounds 6 and 7 , they adopt a binding mode with the same hydrogen bond network as OHHL, including the interaction with Tyr62.

\section{Materials and Methods}

\subsection{Binding Mode Studies}

Docking experiments were performed with the docking module of the ArgusLab software 4.0.1 (Planetaria Software LLC.: Seattle, WA, USA) [14]. The protein model of LuxR [16] was built using SWISS-MODEL [20] with ClustalW [21]. The binding mode of OHHL was obtained using the method described by Estephane and co-workers [15]. Docking experiments were performed with the following parameters: Docking box: $X=Y=Z=15 \AA$, ligand option: flexible; calculation type: Dock; Docking engine: GADock (Genetic Algorithm) [13]; Genetic algorithm dock settings: default advanced parameters; hydrogen bonds were assigned within a distance of $3 \AA$. Figures were generated using PyMOL. The binding mode with hydrogen bonds of 2-AA (magenta) is shown in the following figure (Figure 8) and it is in keeping with that obtained by Kviatkovski and co-workers [10].

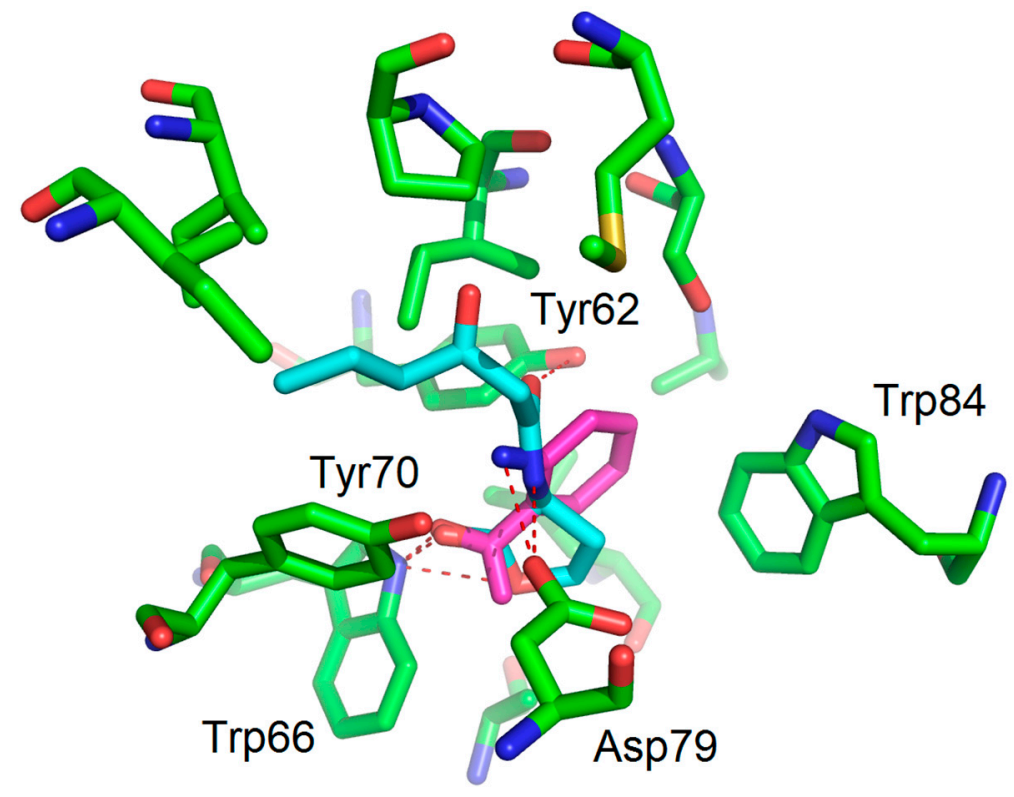

Figure 8. The binding mode (molecular docking) of 2-AA (magenta) within the LuxR model binding site. OHHL is also represented, in cyan.

\subsection{Biological Evaluation}

Compounds were evaluated for their ability to induce bioluminescence (agonistic activity) in the $V$. fischeri QS system. For this purpose, we used the recombinant Escherichia coli biosensor strain NM522 containing the plasmid pSB401. In this plasmid, the luxR and the luxI promoters from $V$. fischeri are associated with the lux structural operon (luxCDABE) from Photorhabdus luminescens $[18,22]$. This biosensor strain produces luminescence with exogenously provided AHL. The activity was measured using a microtiter plate format (Fisher Scientific, Waltham, MA, USA). A competition assay 
(antagonistic activity) was also performed in the presence of $200 \mathrm{nM}$ of 3-oxo-C6-HSL and with simultaneously added analogs. The experiments were carried out in triplicate with a maximum of $2 \%$ DMSO. A negative control was performed in the absence of 3-oxo-C6-HSL and this gave the basal level of bioluminescence in the absence of an inducer. A positive control was performed in the presence of 3-oxo-C6-HSL only.

\subsection{Synthesis}

Chemical reagents were purchased from Sigma Aldrich (St. Louis, MO, USA). Flash chromatography was performed using $60 \mathrm{M}$ silica gel. All reactions were monitored with thin-layer chromatography (TLC) carried out on Merck aluminum silica gel 60-F254 (Darmstadt, Germany) using UV light and a $\mathrm{KMnO}_{4}$ solution as the stain. ${ }^{1} \mathrm{H}$ nuclear magnetic resonance (NMR) spectra were obtained on Bruker ALS300 and DRX300 spectrometers (Billerica, MA, USA).

\subsubsection{General Procedure for the Synthesis of $N$-(2-Nitrophenyl) Amide}

To a solution of 2-nitroaniline (1.0 eq), in $10 \mathrm{~mL}$ anhydrous dichloromethane, was added triethylamine (2.5 eq) and acyl chloride (2.5 eq: butyryl chloride, hexanoyl chloride, octanoyl chloride, decanoyl chloride, 4-phenylbutanoyl chloride was prepared from 4-phenylbutanoic acid and oxalyl chloride with catalytic DMF) at $0{ }^{\circ} \mathrm{C}$. The reaction mixture was left to warm to room temperature, with stirring, for $16 \mathrm{~h}$. The mixture was diluted in $30 \mathrm{~mL}$ dichloromethane and washed with $40 \mathrm{~mL}$ $2 \mathrm{M} \mathrm{HCl}, 40 \mathrm{~mL} 1 \mathrm{M} \mathrm{NaOH}$ and $40 \mathrm{~mL}$ of brine. The organic layer was dried over anhydrous $\mathrm{Na}_{2} \mathrm{SO}_{4}$, evaporated and then the residue was purified by flash chromatography column to give the required products $(29 \%$ to $85 \%$ yield).

3.3.2. General Procedure for the Synthesis of N-phenyl Amide Compounds and N-(2-acetylphenyl) Amide Compounds

To a solution of aniline or 2-Aminoacetophenone (1.0 eq), in $10 \mathrm{~mL}$ anhydrous dichloromethane, was added triethylamine (1.1 eq) and acyl chloride (1.1 eq: butyryl chloride, hexanoyl chloride, octanoyl chloride, decanoyl chloride, 4-phenylbutanoyl chloride was prepared from 4-phenylbutanoic acid and oxalyl chloride with catalytic DMF) at $0{ }^{\circ} \mathrm{C}$. The reaction mixture was left to warm to room temperature, with stirring, for $16 \mathrm{~h}$. The mixture was diluted in $30 \mathrm{~mL}$ dichloromethane and washed with $40 \mathrm{~mL}$ $1 \mathrm{M} \mathrm{HCl}, 40 \mathrm{~mL}$ sat. $\mathrm{NaHCO}_{3}$ and $40 \mathrm{~mL}$ brine. The organic layer was dried over anhydrous $\mathrm{Na}_{2} \mathrm{SO}_{4}$, evaporated and then the residue was purified by flash chromatography column to give the required products ( $36 \%$ to $94 \%$ yields).

N-(2-Nitrophenyl)butyramide (1) see reference [17].

N-(2-Nitrophenyl)hexanamide (2) see reference [17].

N-(2-Nitrophenyl)octanamide (3) see reference [17].

N-(2-Nitrophenyl)decanamide (4). Purification: pentane/diethyl ether = 10/1; yellow solid (43\%); ${ }^{1} \mathrm{H}-\mathrm{NMR}(300 \mathrm{MHz}$, Chloroform-d) $\delta 10.30$ (s, 1H, NH), 8.74 (dd, J = 8.6, $1.4 \mathrm{~Hz}, 1 \mathrm{H}, \mathrm{Ph}-\mathrm{H})$, $8.15(\mathrm{dd}, J=8.5,1.6 \mathrm{~Hz}, 1 \mathrm{H}, \mathrm{Ph}-\mathrm{H}), 7.58(\mathrm{ddd}, J=8.8,7.2,1.6 \mathrm{~Hz}, 1 \mathrm{H}, \mathrm{Ph}-\mathrm{H}), 7.10(\mathrm{ddd}, J=8.5$, 7.2, $1.4 \mathrm{~Hz}, 1 \mathrm{H}, \mathrm{Ph}-\mathrm{H}), 2.42\left(\mathrm{t}, J=7.5 \mathrm{~Hz}, 2 \mathrm{H}, \mathrm{COCH}_{2}\right), 1.69\left(\mathrm{p}, J=7.5 \mathrm{~Hz}, 2 \mathrm{H}, \mathrm{CH}_{2}\right), 1.35-1.11$ $\left(\mathrm{m}, 12 \mathrm{H}, 6 \mathrm{CH}_{2}\right), 0.81\left(\mathrm{t}, J=7.4 \mathrm{~Hz}, 3 \mathrm{H}, \mathrm{CH}_{3}\right) .{ }^{13} \mathrm{C}-\mathrm{NMR}(75 \mathrm{MHz}$, Chloroform-d $) \delta 172.4,136.3,136.1$, 135.2, 125.9, 123.2, 122.3, 38.9, 32.0, 29.5, 29.43, 29.37, 29.26, 25.5, 22.8, 14.2. HR-MS (ESI positive mode) calculated for $\mathrm{C}_{16} \mathrm{H}_{25} \mathrm{~N}_{2} \mathrm{O}_{3}{ }^{+}$: 293.1860. Found: 293.1846 .

N-(2-Nitrophenyl)-4-phenylbutanamide (5). Purification: pentane/AcOEt =15/1; yellow liquid (29\%); ${ }^{1} \mathrm{H}-\mathrm{NMR}$ (300 MHz, Chloroform-d) $\delta 10.38$ (d, $\left.J=5.5 \mathrm{~Hz}, 1 \mathrm{H}, \mathrm{NH}\right), 8.83$ (d, J = 8.3 Hz, 1H, Ph-H), 8.46-8.15 (m, 1H, Ph-H), 7.85-7.49 (m, 1H, Ph-H), 7.44-7.02 (m, 6H, Ph-H), $2.77(\mathrm{t}, J=7.3 \mathrm{~Hz}$, $\left.2 \mathrm{H}, \mathrm{PhCH}_{2}\right), 2.55\left(\mathrm{t}, \mathrm{J}=7.3 \mathrm{~Hz}, 2 \mathrm{H}, \mathrm{COCH}_{2}\right), 2.16\left(\mathrm{q}, \mathrm{J}=7.4 \mathrm{~Hz}, 2 \mathrm{H}, \mathrm{CH}_{2}\right) .{ }^{13} \mathrm{C}-\mathrm{NMR}(75 \mathrm{MHz}$, 
Chloroform- $d$ ) $\delta 171.0,140.2,135.4,135.1,134.0,127.6,125.3,124.9,122.3,121.3,36.9,34.2,25.8$. HR-MS (ESI positive mode) calculated for $\mathrm{C}_{16} \mathrm{H}_{17} \mathrm{~N}_{2} \mathrm{O}_{3}{ }^{+}$: 285.1234. Found: 285.1231.

N-(2-Acetylphenyl)butyramide (6). Purification: pentane/AcOEt $=15 / 1$; white solid (36\%); ${ }^{1} \mathrm{H}-\mathrm{NMR}$ (300 MHz, Chloroform- $d$ ) $\delta 11.71$ (s, 1H, NH), 8.95-8.61 (m, 1H, Ph-H), 7.97-7.79 (m, 1H, Ph-H), 7.55 (dddd, $J=8.5,7.3,1.6,0.5 \mathrm{~Hz}, 1 \mathrm{H}, \mathrm{Ph}-\mathrm{H}), 7.10$ (ddd, $J=8.0,7.3,1.2 \mathrm{~Hz}, 1 \mathrm{H}, \mathrm{Ph}-\mathrm{H}$ ), $2.67\left(\mathrm{~s}, 3 \mathrm{H}, \mathrm{COCH}_{3}\right), 2.41\left(\mathrm{t}, J=7.5 \mathrm{~Hz}, 2 \mathrm{H}, \mathrm{COCH}_{2}\right), 1.92-1.66\left(\mathrm{~m}, 2 \mathrm{H}, \mathrm{CH}_{2}\right), 1.01(\mathrm{t}, J=7.4 \mathrm{~Hz}$, $\left.3 \mathrm{H}, \mathrm{CH}_{3}\right) .{ }^{13} \mathrm{C}-\mathrm{NMR}(75 \mathrm{MHz}$, Chloroform- $d) \delta 202.9,172.7,141.2,135.3,131.7,122.3,121.7,120.8,40.8$, 28.7, 19.1, 13.9. HR-MS (ESI positive mode) calculated for $\mathrm{C}_{12} \mathrm{H}_{15} \mathrm{NNaO}_{2}^{+}$: 228.0995. Found: 228.0985.

N-(2-Acetylphenyl)hexanamide (7) see reference [23].

N-(2-Acetylphenyl)octanamide (8). Purification: pentane/AcOEt $=15 / 1$; colorless oil (85\%); ${ }^{1} \mathrm{H}-\mathrm{NMR}$ (300 MHz, Chloroform-d) $\delta 11.70$ (s, 1H, NH), 8.77 (dd, J = 8.5, $1.2 \mathrm{~Hz}, 1 \mathrm{H}, \mathrm{Ph}-\mathrm{H}), 7.89$ (dd, J = 8.0, $1.6 \mathrm{~Hz}, 1 \mathrm{H}, \mathrm{Ph}-\mathrm{H}), 7.54$ (ddd, $J=8.5,7.2,1.6 \mathrm{~Hz}, 1 \mathrm{H}, \mathrm{Ph}-\mathrm{H}), 7.10$ (ddd, J = 8.0, 7.3, 1.2 Hz, 1H, Ph-H), $2.66\left(\mathrm{~s}, 3 \mathrm{H}, \mathrm{COCH}_{3}\right), 2.43\left(\mathrm{t}, J=7.5 \mathrm{~Hz}, 2 \mathrm{H}, \mathrm{COCH}_{2}\right), 1.83-1.62\left(\mathrm{~m}, 2 \mathrm{H}, \mathrm{CH}_{2}\right), 1.44-1.16\left(\mathrm{~m}, 8 \mathrm{H}, 4 \mathrm{CH}_{2}\right)$, 0.96-0.72 (t, $\left.J=7.4 \mathrm{~Hz}, 3 \mathrm{H}, \mathrm{CH}_{3}\right) .{ }^{13} \mathrm{C}-\mathrm{NMR}(75 \mathrm{MHz}$, Chloroform- $d$ ) $\delta 202.9,172.9,141.3,135.3,131.7$, 122.3, 121.8, 120.9, 38.9, 31.8, 29.3, 29.1, 28.7, 25.7, 22.7, 14.2. HR-MS (ESI positive mode) calculated for $\mathrm{C}_{16} \mathrm{H}_{24} \mathrm{NO}_{2}^{+}:$262.1802. Found: 262.1793.

N-(2-Acetylphenyl)decanamide (9) see reference [24].

N-(2-Acetylphenyl)-4-phenylbutanamide (10). Purification: pentane/AcOEt =13/1; colorless oil (44\%); ${ }^{1} \mathrm{H}-\mathrm{NMR}(300 \mathrm{MHz}$, Chloroform-d) $\delta 11.75$ (s, 1H, NH), 8.80 (dd, J = 8.5, 1.2 Hz, 1H, Ph-H), 7.92 (dd, J = 8.0, 1.6 Hz, 1H, Ph-H), 7.70-7.50 (m, 1H, Ph-H), 7.41-7.06 (m, 6H, Ph-H), 2.75 (t, J = 7.4 Hz, 2H, PhCH $\mathrm{H}_{2}$, $2.69\left(\mathrm{~s}, 3 \mathrm{H}, \mathrm{COCH}_{3}\right), 2.50\left(\mathrm{t}, J=7.5 \mathrm{~Hz}, 2 \mathrm{H}, \mathrm{COCH}_{2}\right), 2.20-2.05\left(\mathrm{~m}, 2 \mathrm{H}, \mathrm{CH}_{2}\right) .{ }^{13} \mathrm{C}-\mathrm{NMR}(75 \mathrm{MHz}$, Chloroform- $d$ ) $\delta 202.9,172.4,141.6,141.2,135.3,131.7,128.6,128.5,126.1,122.4,121.8,120.9,38.1,35.3,28.7$, 27.1. HR-MS (ESI positive mode) calculated for $\mathrm{C}_{18} \mathrm{H}_{20} \mathrm{NO}_{2}{ }^{+}: 282.1489$. Found: 282.1483.

N-Phenylbutyramide (11) see reference [25].

N-Phenylhexanamide (12) see reference [26].

N-Phenyloctanamide (13) see reference [27].

N-Phenyldecanamide (14) see reference [28].

N,4-Diphenylbutanamide (15) see reference [29].

\section{Conclusions}

In our search for a novel scaffold that is active on LuxR-regulated QS and based on a benzenic backbone, we designed an original combination of substituents, notably the nitro and acylated amine groups. Docking experiments demonstrated that this scaffold replaces exactly the lactone moiety of AHL within the binding site of LuxR. However, variations were observed in the hydrogen network between the ligands and some key amino acids of the binding site, with some significant results revealed by the biological evaluation. In particular, the absence of the hydrogen bond with Tyr62 appears to be essential for antagonistic activity in this new family of aniline and nitroaniline QS inhibitors. The design and the docking experiments were validated by biological assays showing significant inhibitory activity, notably for N-(2-nitrophenyl)butyramide (1). Thus, 2-nitro aniline, a very simple and versatile scaffold, has proved to be a valuable basis for designing novel QS-active candidates.

Supplementary Materials: Supplementary materials are available online. ${ }^{1} \mathrm{H}-\mathrm{NMR}$ spectra.

Acknowledgments: Financial support from MESR and CNRS is gratefully acknowledged. Sizhe Li would like to thank the Chinese Scholarship Council for his grant. The authors thank Valerie James for improving the English of the manuscript. 
Author Contributions: Y.Q. and L.S. conceived and designed the experiments; S.L. performed the experiments; Y.Q. and L.S. analyzed the data; J.W. contributed reagents/materials/analysis tools; Y.Q. and L.S. wrote the paper.

Conflicts of Interest: The authors declare no conflict of interest.

\section{References}

1. Garg, N.; Manchanda, G.; Kumar, A. Bacterial quorum sensing: Circuits and applications. Antonie Leeuwenhoek 2014, 105, 289-305. [CrossRef] [PubMed]

2. Brackman, G.; Coenye, T. Quorum sensing inhibitors as anti-biofilm agents. Curr. Pharm. Des. 2015, 21, 5-11. [CrossRef] [PubMed]

3. LaSarre, B.; Federle, M.J. Exploiting quorum sensing to confuse bacterial pathogens. Microbiol. Mol. Biol. Rev. 2013, 77, 73-111. [CrossRef] [PubMed]

4. Reuter, K.; Steinbach, A.; Helms, V. Interfering with bacterial quorum sensing. Perspect. Med. Chem. 2016, 8, 1-15. [CrossRef] [PubMed]

5. Stevens, A.M.; Queneau, Y.; Soulere, L.; von Bodman, S.; Doutheau, A. Mechanisms and synthetic modulators of AHL-dependent gene regulation. Chem. Rev. 2011, 111, 4-27. [CrossRef] [PubMed]

6. Tay, S.B.; Yew, W.S. Development of quorum-based anti-virulence therapeutics targeting Gram-negative bacterial pathogens. Int. J. Mol. Sci. 2013, 14, 16570-16599. [CrossRef] [PubMed]

7. Wang, Y.; Ma, S. Small molecules modulating AHL-based quorum sensing to attenuate bacteria virulence and biofilms as promising antimicrobial drugs. Curr. Med. Chem. 2014, 21, 296-311. [CrossRef] [PubMed]

8. Dekimpe, V.; Deziel, E. Revisiting the quorum-sensing hierarchy in Pseudomonas aeruginosa: The transcriptional regulator RhlR regulates LasR-specific factors. Microbiology 2009, 155, 712-723. [CrossRef] [PubMed]

9. Drees, S.L.; Fetzner, S. PqsE of Pseudomonas aeruginosa acts as pathway-specific thioesterase in the biosynthesis of alkylquinolone signaling molecules. Chem. Biol. 2015, 22, 611-618. [CrossRef] [PubMed]

10. Kviatkovski, I.; Chernin, L.; Yarnitzky, T.; Frumin, I.; Sobel, N.; Helman, Y. Pseudomonas aeruginosa activates the quorum sensing LuxR response regulator through secretion of 2-aminoacetophenone. Chem. Commun. 2015, 51, 3258-3261. [CrossRef] [PubMed]

11. Zou, Y.; Nair, S.K. Molecular basis for the recognition of structurally distinct autoinducer mimics by the Pseudomonas aeruginosa LasR quorum-sensing signaling receptor. Chem. Biol. 2009, 16, 961-970. [CrossRef] [PubMed]

12. O'Reilly, M.C.; Blackwell, H.E. Structure-based design and biological evaluation of triphenyl scaffold-based hybrid compounds as hydrolytically stable modulators of a LuxR-Type quorum sensing receptor. ACS Infect. Dis. 2016, 2, 32-38. [CrossRef] [PubMed]

13. Morris, G.M.; Goodsell, D.S.; Halliday, R.S.; Huey, R.; Hart, W.E.; Belew, R.K.; Olson, A.J. Automated docking using a lamarckian genetic algorithm and an empirical binding free energy function. J. Comput. Chem. 1998, 19, 1639-1662. [CrossRef]

14. Thompson, M.A. ArgusLaB 4.0.1, Planetaria Software LLC.: Seattle, WA, USA, 2004.

15. Estephane, J.; Dauvergne, J.; Soulere, L.; Reverchon, S.; Queneau, Y.; Doutheau, A. N-Acyl-3-amino-5H-furanone derivatives as new inhibitors of LuxR-dependent quorum sensing: Synthesis, biological evaluation and binding mode study. Bioorg. Med. Chem. Lett. 2008, 18, 4321-4324. [CrossRef] [PubMed]

16. Soulere, L.; Frezza, M.; Queneau, Y.; Doutheau, A. Exploring the active site of acyl homoserine lactones-dependent transcriptional regulators with bacterial quorum sensing modulators using molecular mechanics and docking studies. J. Mol. Graph. Model. 2007, 26, 581-590. [CrossRef] [PubMed]

17. Darvesh, S.; McDonald, R.S.; Darvesh, K.V.; Mataija, D.; Mothana, S.; Cook, H.; Carneiro, K.M.; Richard, N.; Walsh, R.; Martin, E. On the active site for hydrolysis of aryl amides and choline esters by human cholinesterases. Bioorg. Med. Chem. 2006, 14, 4586-4599. [CrossRef] [PubMed]

18. Reverchon, S.; Chantegrel, B.; Deshayes, C.; Doutheau, A.; Cotte-Pattat, N. New synthetic analogues of $\mathrm{N}$-acyl homoserine lactones as agonists or antagonists of transcriptional regulators involved in bacterial quorum sensing. Bioorg. Med. Chem. Lett. 2002, 12, 1153-1157. [CrossRef]

19. McInnis, C.E.; Blackwell, H.E. Design, synthesis, and biological evaluation of abiotic, non-lactone modulators of LuxR-type quorum sensing. Bioorg. Med. Chem. 2011, 19, 4812-4819. [CrossRef] [PubMed]

20. Schwede, T.; Kopp, J.; Guex, N.; Peitsch, M.C. SWISS-MODEL: An automated protein homology-modeling server. Nucleic Acids Res. 2003, 31, 3381-3385. [CrossRef] [PubMed] 
21. Thompson, J.D.; Higgins, D.G.; Gibson, T.J. CLUSTAL W: Improving the sensitivity of progressive multiple sequence alignment through sequence weighting, position-specific gap penalties and weight matrix choice. Nucleic Acids Res. 1994, 22, 4673-4680. [CrossRef] [PubMed]

22. Frezza, M.; Castang, S.; Estephane, J.; Soulere, L.; Deshayes, C.; Chantegrel, B.; Nasser, W.; Queneau, Y.; Reverchon, S.; Doutheau, A. Synthesis and biological evaluation of homoserine lactone derived ureas as antagonists of bacterial quorum sensing. Bioorg. Med. Chem. 2006, 14, 4781-4791. [CrossRef] [PubMed]

23. Jones, C.P.; Anderson, K.W.; Buchwald, S.L. Sequential Cu-catalyzed amidation-base-mediated camps cyclization: A two-step synthesis of 2-Aryl-4-quinolones from o-halophenones. J. Org. Chem. 2007, 72, 7968-7973. [CrossRef] [PubMed]

24. Verma, A.; Kumar, S. Selective Oxidative Decarbonylative Cleavage of Unstrained C(sp(3))-C(sp(2)) Bond: Synthesis of Substituted Benzoxazinones. Org. Lett. 2016, 18, 4388-4391. [CrossRef] [PubMed]

25. Correa, A.; Elmore, S.; Bolm, C. Iron-catalyzed N-Arylations of amides. Chem. Eur. J. 2008, 14, 3527-3529. [CrossRef] [PubMed]

26. Jammi, S.; Sakthivel, S.; Rout, L.; Mukherjee, T.; Mandal, S.; Mitra, R.; Saha, P.; Punniyamurthy, T. CuO nanoparticles catalyzed C-N, C-O, and C-S cross-coupling reactions: Scope and mechanism. J. Org. Chem. 2009, 74, 1971-1976. [CrossRef] [PubMed]

27. Hosseini-Sarvari, M.; Sodagar, E.; Doroodmand, M.M. Nano sulfated titania as solid acid catalyst in direct synthesis of fatty acid amides. J. Org. Chem. 2011, 76, 2853-2859. [CrossRef] [PubMed]

28. Henry, C.; Bolien, D.; Ibanescu, B.; Bloodworth, S.; Harrowven, D.C.; Zhang, X.L.; Craven, A.; Sneddon, H.F.; Whitby, R.J. Generation and trapping of Ketenes in flow. Eur. J. Org. Chem. 2015, 2015, 1491-1499. [CrossRef] [PubMed]

29. Kim, S.; Lim, K.C. Tin-free radical carbonylation of alkylsulfonyl derivatives into alkylcarbonyl derivatives. Chem. Asian J. 2008, 3, 1692-1701. [CrossRef] [PubMed]

Sample Availability: Samples of the compounds 1-15 are available from the authors.

(C) 2017 by the authors. Licensee MDPI, Basel, Switzerland. This article is an open access article distributed under the terms and conditions of the Creative Commons Attribution (CC BY) license (http:// creativecommons.org/licenses/by/4.0/). 